Удк 1(091)+274](4)

\title{
ДЗЮБАК РОМАН,
}

аспірант кафедри філософії,

Львівський національний університет імені Івана Франка

\section{ВПЛИВ РЕФОРМАЦІЙНИХ ЧИННИКІВ НА ПРОЦЕС СЕКУЛЯРИЗАЦІї}

У статті розглянуто роль Реформації у процесі секуляризації крізь призму сучасних історико-філософських досліджень Ч. Тейлора та Б. Грегорі. На основі виділених сфер впливу Реформації, що є спільними для розвідок Ч. Тейлора та Б. Грегорі, здійснено порівняльний аналіз їхніх концепцій. Продемонстровано, що Ч. Тейлор здебільшого зосереджує свою увагу на таких наслідках Реформації, що сприяли суспільному поступу, як розчаклування простору, поширення моральних стандартів та реабілітація праці. Водночас, він виділяє загострення доктринального питання про передвибрання в протестантизмі як одну 3 перешкод для сприйняття християнства інтелектуалами епохи Модерну. Зазначено, що Б. Грегорі наголошує лише на тих наслідках Реформації, що мали негативний характер. Серед них він виділяє заперечення середньовічного сакраментального світогляду, суб'єктивацію моральних норм, а також необмежене накопичення матеріальних благ. Указано на недостатню обґрунтованість тверджень Б. Грегорі про формування доктрин протестантизму в межах метафізичної однозначності буття. 3'ясовано, що серед результатів Реформації були як такі, що сприяли соціальному поступу, так $\mathrm{i}$ ті, що призвели до появи нових етичних проблем.

Ключові слова: Реформація; секуляризація; християнство; розчаклування; метафрізична однозначність буття.

Постановка проблеми. Керуючись прагненням проаналізувати історію розгортання секуляризації, не можемо залишити поза увагою роль християнської спадщини, а зокрема Реформації в цьому процесі. У своїй праці "Секулярна доба" канадський фрілософ Ч. Тейлор, розглядаючи Реформацію, значною мірою наслідує ідеї М. Вебера та виділяє такі її основні наслідки, як світоглядний аспект розчаклування простору та часу, поширення моральних норм на широкі верстви населення, а також вплив протестантської етики праці. Варто зазначити, що "Секулярна доба", побачивши світ у 2007 році, викликала зацікавлення історико-фрілософською проблематикою процесу секуляризації. Так, американський історик Б. Грегорі у 2012 році опублікував працю "Ненавмисна Реформація: як релігійна революція секуляризувала суспільство". У цій книзі він обстоює думку про те, що Реформація, будучи відходом від латинського християнства, стала причиною формування науки в секулярних термінах, виключення теології з інтелектуального дискурсу, а також призвела до суб'єктивації моралі та появи західного суспільства споживацтва. Якщо в концепції Ч. Тейлора Реформація постає фактором поступу тогочасного суспільства, то, на думку Б. Грегорі, вона спричинила цілу низку соціальних проблем не лише ранньомодерного періоду, але й сьогодення. Таким чином, постає потреба аналізу ролі Реформації в секуляризаційному процесі на основі праць "Секулярна доба" [Тейлор, 2013] та "Ненавмисна Реформація: як релігійна революція секуляризувала суспільство" [Gregory, 2012].

Аналіз досліджень і публікацій. Серед вітчизняних науковців бачення Реформації в наративі секуляризації Ч. Тейлора розглядають М. Черенков, А. Довго- чуб, О. Яроцька та А. Денисенко. Також М. Черенков у своїй статті "Реформація і апокаліпсис секулярності" [Черенков, 2017] звертається до праці Б. Грегорі "Ненавмисна Реформація: як релігійна революція секуляризувала суспільство". Зазначимо, що оскільки вказана книга Б. Грегорі на сьогодні не $є$ перекладеною українською мовою, здебільшого вона залишається поза увагою українських дослідників.

У нашій статті ми насамперед звертатимемося до праць "Секулярна доба" Ч. Тейлора та "Ненавмисна Реформація: як релігійна революція секуляризувала суспільство" Б. Грегорі, а також до розвідок таких західних дослідників, як Дж. Пеннелл, П. Петерсон, Дж. Рівс, Дж. Сміт, М. Маккорд Адамс, Д. Аерс та Р. Лео.

Мета статті - на основі компаративного аналізу історико-фрілософських досліджень Б. Грегорі та Ч. Тейлора з'ясувати, чи сприяла Реформація поступу тогочасного суспільства чи, навпаки, фігурувала причиною нових проблем унаслідок відділення від латинського християнства.

Виклад основного матеріалу. Розглядаючи концепції Реформації Ч. Тейлора та Б. Грегорі, означимо змістовну та методологічну основи, на яких можливе здійснення цього аналізу. По-перше, це спільний для обох розвідок об'єкт досліджень. Ч. Тейлор та Б. Грегорі розглядають секуляризацію в процесі ії історичного становлення та виокремлюють Реформацію як явище, що значною мірою змінило тогочасні релігійні та соціальні умови, а також вплинуло на формування ранньомодерної Європи з її секулярним характером. Подруге, обох дослідників об'єднує спільна методологія. У своїх працях Ч. Тейлор та Б. Грегорі простежують історико-фрілософрські корені секуляризації та фрормують 
власні наративні концепції цього явища на основі генеалогічного методу. Спільним для обох авторів $€$ також їхнє бачення минулого як ключа до розуміння сучасності. У своїй праці "Секулярна доба" Ч. Тейлор шукає відповідь на запитання, як змінився Західний світ упродовж останніх п'ятисот років, перейшовши від суспільства пізнього середньовіччя, у якому віра в Бога була характерною ознакою всіх його членів, до суспільства сьогодення, у якому віра в Бога $є$ не лише одним вибором із цілої низки можливих, але й таким, що часто розглядається, як малоймовірний [Тейлор, 2013: 49]. Канадський дослідник Дж. Сміт, вивчаючи книгу "Секулярна доба", поставив запитання: "Чи можемо ми уявити екзистенційну мапу нашої секулярної доби, яка була би насправді здатна допомогти нам знайти себе та дати нам відчуття того, де ми перебуваємо?" [Smith, 2014: 2]. Саме такою мапою, на його думку, є праця Ч. Тейлора "Секулярна доба". Водночас Б. Грегорі вбачає в подіях п'ятисотрічної давнини, а саме в Реформації, причини низки характерних рис сучасності. Зокрема, на думку американського дослідника, труднощі обґрунтування спільної етичної основи для плюралістичного суспільства сьогодення, споживацький характер сучасної західної цивілізації та секулярний науковий дискурс $є$ наслідками ідей протестантизму. У своїй книзі Б. Грегорі наводить цитату В. Фолкнера, яка влучно ілюструє його власне бачення впливу минулого на сьогодення: "Минуле ніколи не $є$ мертвим. Воно навіть не $€$ минулим" [Gregory, 2012: 1].

Водночас, дослідники акцентують на різних аспектах впливу Реформації на формування секуляризації. Попри цю відмінність, можна виділити тематичні блоки, що розглядаються обома авторами. Зокрема, зміни, викликані Реформацією у сфері етики, економіки та концепції навколишнього світу. Також Б. Грегорі та Ч. Тейлор розглядають тему дискредитації християнства як ненавмисного результату ідей протестантизму. Варто зазначити, що праці Б. Грегорі та Ч. Тейлора $є$ значними за обсягом, відтак фрормат статті не дозволяє докладно розглянути всі сторони концепцій кожного з дослідників, тому ми зупинимося лише на основних тематичних блоках, спільних для них обох.

Тема змін у середньовічній концепції простору має центральне значення під час розгляду Реформації в дослідженні Ч. Тейлора. Описуючи "зачаклований світ" середньовіччя, канадський дослідник вказує на те, що в цей період розмежування "фрізичного" та "ментального" ще не відбулося. Простір у тогочасних уявленнях постає вмістилищем зовнішніх щодо людини надприродних сил. 3 одного боку, це були численні злі духи, що населяли безлюдні простори природи та могли заподіяти шкоду людині. 3 іншого боку, добродійні святі, прихильність та захист яких можна здобути, здійснюючи молитви. Для опису стану вразливості людської природи до безпосереднього впливу надприродних діячів попри волю людини Ч. Тейлор вводить поняття "пористого я" (porous self) [Тейлор, 2013: 65].

Окрім цього, як зазначає Ч. Тейлор, у тогочасному розумінні простір не мав гомогенного характеру. У ньому знаходилися місця та речі, що є концентраціями надприродних сил, зокрема храми, євхаристія, реліквії та мощі. Такі предмети могли розв'язати проблему людини, зокрема зцілити їі від хвороби, або ж могли зашкодити їй, відплативши за нешанобливе ставлення, наприклад, у разі їх крадіжки [Тейлор, 2013: 60-64]. У такий спосіб особа, перебуваючи в зачаклованому світі, була в певному полі страху. У середовищі, наповненому злими духам, віра в існування Бога та опіку святих $\epsilon$ прихистком для людини. Вона змушена звертатися до певного роду "доброї магії", зокрема брати участь у ритуальних процесіях своєї парафії чи паломництві до святих місць, шанувати реліквії та здійснювати молитви до святих заступників [Тейлор, 2013: 75]. У цих умовах, відхід від віри в Бога значною мірою немислимий, оскільки він означає віддати себе на поталу демонічним силам.

Реформація значно змінила цей стан справ. Унаслідок проголошення принципу "Sola scriptura", авторитет у питаннях віри був перенесений з інституту церкви до Святого Письма. Переклад Біблії мовою, зрозумілою пересічним жителям, надав можливість читати їі широкому загалу. У світлі нових інтерпретацій Святого Писання постає нова форма побожності, згідно з якою зовнішній аспект культової діяльності радикально спрощується. Унаслідок акценту на суверенність Бога в працях реформаторів, сакральні предмети сприймаються як такі, що обмежують Його всемогутність, а отже, мають бути відкинені [Тейлор, 2013: 133]. Таким чином, простір почав позбуватися місць чи предметів, що були концентраціями надприродної сили, відповідно, почав набувати дедалі більшої гомогенності.

Іншим аспектом розчаклування, який розглядає Ч. Тейлор, $є$ повне скасування магії. Так, простір, населений злими духами, здатними зашкодити "пористому я", був небезпечним середовищем та був причиною остраху в жителів середньовіччя. Однак певною мірою "добра магія" також була причиною занепокоєння, оскільки, виявляючи до неї пошану, необхідно було триматися від неї на безпечній відстані. Реформація спричинила радикальну зміну, коли весь цей страх був сконцентрований та перетворений у страх перед Богом тим, хто є гарантом перемоги над будь-якою магією та демонами. Якщо до цього страх перед магією спричиняв турботу та пригнічення, то страх перед Богом наділяв піднесенням. Відбулося те, що Ч. Тейлор назвав "перевертанням поля страху" [Тейлор, 2013: 124-125]. У цей спосіб формується нове розуміння себе. На заміну "пористому я", яке може бути об'єктом безпосереднього впливу надприродних діячів, приходить "ізольоване я", що є закрите для такого впливу [Тейлор, 2013: 52-53].

Результатом розчаклування простору є поява інструментального ставлення до навколишнього середовища. Як стверджує Ч. Тейлор, простір без священних згустків утрачає певні обмеження, які накладалися ними. Відтепер людина отримала свободу переформатовувати цей простір на свій лад, зважаючи на Божий задум [Тейлор, 2013: 134].

Отже, якщо Ч. Тейлор у своїй книзі "Секулярна доба" розглядає зміни, спричинені Реформацією в концепції навколишнього світу крізь протиставлення "людина світ", то Б. Грегорі розглядає їх крізь призму стосунку "Бог - світ". Так, Б. Грегорі у своїй праці вбачає в Реформації одну з причин модерного протиставлення релігії та науки, згідно з яким наука заперечує існування Бога. Він наводить приклад одного з представників напряму "Нового атеїзму" Р. Докінза. Так, у своїй праці "Ілюзія Бога" Р. Докінз стверджує, що існування Бога $є$ науковою гіпотезою, а отже, вона може бути підтверджена чи спростована на основі загальної наукової методології. Однак, як зауважує Б. Грегорі, згідно з традиційним християнським уявленням, Бог як творець $€$ трансцендентним щодо свого творіння, а отже, позапросторовим та позачасовим. Зважаючи на це, американський історик стверджує, що наука на основі емпіричного дослідження іманентної дійсності не може підтвердити чи спростувати існування трансцендентного Бога, оскільки це виходить за її компетенцію [Gregory, 2012: 
55-56]. Отже, погляд, згідно з яким наука спростовує існування Бога, $є$ або хибним, або в цьому твердженні Бог розглядається не в традиційний християнський спосіб. На думку Б. Грегорі, причина полягає саме в зміні традиційного уявлення щодо характеру буття Бога, що відбулась у період пізнього середньовіччя та стала тлом мислення, у межах якого формувалися доктрини Реформації.

Б. Грегорі вважає, що зміна традиційного християнського розуміння трансцендентного Бога відбувається з появою метафрізичної однозначності буття Іоанна Дунса Скота. До цього часу у фрілософіії томізму Бог розглядався не як той, що "є" (лат. ens), але є "чистим актом буття" (лат. esse), до якого долучалось усе творіння й завдяки чому воно містично підтримувалось [Gregory, 2012: 38]. У концепції томізму Бог поставав як радикально відмінний від свого творіння. Проте, як зазначає Б. Грегорі, Д. Скот уважав небезпечним характеризувати Бога як абсолютно Іншого, оскільки, у такому разі, поставала загроза неможливості будь-яких висловлювань щодо Нього. Тому, шукаючи спільну для Творця та творіння рису, середньовічний мислитель виділив для них обох характеристику "бути" (лат. ens), чим додав Бога "у спільний онтологічний та каузальний порядок зі своїм творінням" [Gregory, 2012: 52]. Така "іманентизація" Бога до певної міри асимілювала Його зі своїм творінням, чим надала можливість у майбутньому робити твердження про "спростування" існування Бога наукою [Gregory, 2012: 52].

Надалі лінію роздумів Д. Скота щодо буття Бога поглиблював у своїх творах інший представник фрілософрії номіналізму В. Оккам. Так, Б. Грегорі виділяє принцип простоти, відомий як "бритва Оккама", як ще одну передумову виключення Бога з природознавчих наук у період Нового часу. На думку американського історика, оскільки навколишній світ, набувши автономності, міг бути пояснений безвідносно до будь-чого іншого як система самодостатньої каузальності, згідно з принципом Оккама, причини долучати Бога до світобудови вже не було [Gregory, 2012: 52].

Б. Грегорі зазначає, що метафрізична однозначність буття після своєї появи не мала широкого впливу, оскільки стосувалася "стратосфери високої інтелектуальної культури" [Gregory, 2012: 37], до якої мала можливість долучитися лише мізерна частка населення. Він указує на те, що "соціальний, політичний, ширший культурний та економічний вплив ідеї Д. Скота в ранньому XIV столітті [...] був нульовий" [Gregory, 2012: 37]. Попри це, на його думку, зміна в розумінні Бога, спричинена мислителями пізнього середньовіччя, мала великий вплив на фоормування секулярного характеру Модерну в довготерміновій перспективі.

Б. Грегорі вважає, що, оскільки Реформація постала на теологічному ґрунті латинського християнства, її представники мислили в межах метафізичної настанови однозначності буття. На його думку, про це свідчить радикальний перегляд представниками протестантизму низки питань щодо проявів Бога в межах фрізичного світу. Серед них були питання літургії, благодаті, таїнств, зокрема присутності Христа в Євхаристії, можливості чудес у післяапостольський період та інші. Б. Грегорі стверджує, що зміна статусу буття Бога в метафрізичній однозначності буття Д. Скота та В. Оккама призвела до заперечення сакраментального світогляду та перегляду стосунку "Бог - навколишній світ" у період Реформації, що своєю чергою уможливило формування наукового дискурсу у винятково натуралістичних термінах [Gregory, 2012: 40-41]. Таким чином, згідно з цією концепцією, Реформація поглибила сформульований у період піз- ньої схоластики відхід від томістського розуміння буття Бога, утвердивши Иого привнесення в спільну онтологічну площину з фізичним світом, що згодом надало можливість "спростування" існування Бога в науці періоду Просвітництва

Як уже зазначалося, основним аспектом, на якому Ч. Тейлор зосереджує свою увагу в розгляді Реформації, $€$ розчаклування. Однак, на думку Б. Грегорі, "хоча існує складна історія, яку необхідно розповісти, про відношення між пізньосередньовічною метафрізикою та епістемологічними ідеями з однієї сторони та відповідними твердженнями протестантських реформаторів 3 іншої, Протестантизм як такий не розчакловував світ" [Gregory, 2012: 41]. Американський дослідник уважає, що представники Реформації формулювали доктрини, певною мірою мислячи в рамках метафізичної однозначності буття. Це призвело не до розчаклування світу, але до заперечення сакраментального світогляду середньовічного християнства в питаннях церковних таїнств та до перегляду способу, у який Бог може проявляти себе в межах матеріального світу. Так, Б. Грегорі висловлює думку про те, що ототожнення сакраментального світогляду середньовічного християнства 3 магією $є$ некоректним. Він уважає, що ця тенденція базується на основі "метафрізичного натуралізму" та $є$ властивою "еволюційному наративу прогресивної секуляризації" [Gregory, 2012: 403].

Причина різниці в оцінках розчаклування як наслідку Реформації криється у відмінності значень, які Ч. Тейлор та Б. Грегорі надають цьому поняттю. Хоча обоє дослідників, уживаючи термін "розчаклування" у своїх працях, посилаються на М. Вебера, вони розуміють його в різний спосіб. Для Ч. Тейлора розчаклування - це процес, унаслідок якого простір та час утрачають риси гетерогенності: простір перестає бути наповненим духами та концентраціями надприродної сили, тоді як час втрачає свою багатошарову структуру, згідно з якою профанний час співвідноситься 3 вищими часами та вічністю. Б. Грегорі розглядає розчаклування в значенні кінцевого виключення Бога зі світоглядного горизонту. Згідно з цією концепцією, Реформація як релігійне явище в межах західного християнства, докорінно переосмислюючи низку доктрин, не усувала Бога з інтелектуального дискурсу, а отже, не розчакловувала світу.

Також, обоє дослідників розходяться у своїх оцінках змін, спричинених ідеями Реформації. Так, Ч. Тейлор розглядає розчаклування простору як чинник суспільного поступу, на основі якого в межах релігійного світогляду формуватиметься інструментальне ставлення до навколишнього світу. Тоді як Б. Грегорі вбачає в запереченні сакраментальності середньовічного християнства поворот від традиційного погляду на те, як трансцендентний Творець може проявляти себе в межах іманентного світу. На його думку, саме на цій основі згодом відбудеться виключення Бога з інтелектуального дискурсу в епоху Модерну.

Зауважимо, що твердження щодо метафрізики Д. Скота як передумови для подальшого виключення Бога 3 інтелектуального дискурсу викликає запитання, на яких наголошують критики праці Б. Грегорі. Зокрема, Дж. Рівс у своєму критичному огляді вказує на брак історичного підґрунтя в дослідженні Б. Грегорі. Дж. Рівс стверджує, що низка дослідників доробку Д. Скота не знаходять підґрунтя в працях середньовічного мислителя для ствердження відходу від традиційного розуміння буття Бога [Reeves, 2017: 115]. На думку М. Маккорд Адамс, теорія однозначності буття Д. Скота мала лінгвістичний характер, а не метафізичний та не суперечила поширеному на той час погляду, згідно з яким матеріаль- 
не буття певним чином бере участь у божественному бутті [Reeves, 2017: 115]. Іншою лінією критики праці "Ненавмисна Реформація" є недостатня аргументація твердження щодо впливу напрацювань Д. Скота на представників Реформації. Так, Дж. Рівс посилається на сучасне дослідження праць реформаторів, згідно з яким мовні аспекти висловлювань щодо буття Бога, характерні для теорії однозначності буття, не є притаманними традиційній протестантській теологічній думці [Reeves, 2017: 115]. Це означає, що питання Євхаристії та зовнішньої атрибутики культової діяльності були переглянуті реформаторами не в результаті метафрізичної трансформації пізнього середньовіччя, а внаслідок інших тогочасних теологічних та історико-соціальних чинників. Так само, Дж. Рівс уважає, що автономний характер природи з необхідністю не виключає Бога зі світоглядної картини світу згідно з принципом простоти В. Оккама, оскільки науковцям, що фоормували механістичну картину світу, також було притаманне бачення цього світу як творіння, що вказує на свого Творця, так само як годинник вказує на існування майстра, який його виготовив [Reeves, 2017: 115]. Отже, ці критичні зауваження вказують на слабкі місця концепції впливу Рефрормації в контексті відношення "Бог - навколишній світ" у праці Б. Грегорі, ставлячи під сумнів його тезу про формування доктрин протестантизму на основі метафрізичної однозначності буття.

Заслугою Реформації, на думку Ч. Тейлора, також $є$ поширення моральних стандартів на широкі верстви населення. Дослідник зазначає, що в період пізнього середньовіччя в межах латинського християнства відбулась низка спроб перетворення суспільства згідно з вимогами Євангелія. Ч. Тейлор уважає, що ця тенденція в латинському християнстві свідчить про наявність у той час певної "спраги порядку", відчуття необхідності змін [Тейлор, 2013: 141]. Він указує на напруження в суспільстві, що було спричинене ієрархічною рівновагою між духівництвом та мирянами. Так, згідно із середньовічною концепцією взаємодоповнення соціальних станів, "монахи за всіх моляться, пани всіх захищають, селяни за всіх працюють" [Тейлор, 2013: 80]. Однак ці види діяльності мали різний ступінь гідності. Зокрема, духівництво було більш шанованим покликанням, оскільки воно могло відповідати християнським нормам у їхній повноті та вести за собою решту суспільства, яка не мала можливості дотримуватись високих стандартів чернечого життя.

Проголошення в протестантизмі доктрини священства всіх вірних означало, що всі християни, незалежно від суспільного стану, однаковою мірою покликані служити Богові. Оскільки все життя християнина освячувалося, служіння Богу могло здійснюватися не в молитовному житті в келії, але в щоденній роботі, сімейних турботах чи громадській діяльності. Межа між сакральною та профанною діяльністю втратила свою значущість. Унаслідок цього чернецтво позбавилося характеру особливої духовної посвяченості. Відтепер усі були покликані відповідати високим нормам моралі: "Більше не було звичайних та надзвичайних християн [...]. Усі християни мали бути цілком та однаково відданими" [Тейлор, 2013: 129]. Новий вид побожності призвів до переформатування тодішнього суспільства. Залучення широких верств населення до морального життя потребувало формування внутрішньої етичної настанови та дисципліни характеру. У такий спосіб релігійна потреба трансформації суспільства згідно з Євангелієм співпала з вимогами цивілізованості. Як зазначає Ч. Тейлор, згодом на цій основі формуватимуться ранньомодерні дисциплінарні суспільства.
У своєму дослідженні Б. Грегорі пов'язує зміни в етиці, що відбулись унаслідок Реформації, з появою нових інтерпретацій біблійних текстів. Проголошення в протестантизмі тези "Sola Scriptura" перенесло авторитет у питаннях віри з церковної інституції до Святого Писання. Водночас поява перекладів Біблії розмовною мовою та поширення друкарства надали можливість читати та розуміти Писання широкому колу читачів. Однак у результаті цього з'явилися численні суперечливі інтерпретації біблійних уривків, що спричинили низку поділень у межах протестантизму. Унаслідок нездатності дійти згоди 3 низки питань Реформація призвела до появи не однієї альтеративної точки зору, але цілої низки розбіжних поглядів. На думку Б. Грегорі, гетерогенний характер протестантизму в питаннях доктрин, а також відмінність акцентів у питаннях чеснот між протестантами та католиками призвели до суб'єктивації моральних норм [Gregory, 2012: 204-205]. Моральні стандарти почали сприйматися як такі, що є предметами особистих уподобань. Якщо ця зміна відбулась у суспільній площині, то на рівні держав "субстантивна етика блага" була замінена "формальною модерною етикою прав" [Gregory, 2012: 211]. Через розбіжності поглядів між католиками та протестантами щодо визначення блага та його соціальної реалізації, держава певною мірою відсторонилася від цієї дискусії. Відтепер держава припинила встановлювати загальне благо. її функція стала полягати в захисті права особи визначати це благо самостійно в умовах різноманіття поглядів. Ненавмисним наслідком суперечок, спричинених Реформацією, стала поява західного "гіперплюралізму" в питаннях моралі та сенсу життя. У такий спосіб Реформація, на думку Б. Грегорі, "припинила більш ніж тисячолітні спроби створити в латинському Заході уніфріковану моральну спільноту через християнство" [Gregory, 2012: 203].

Варто зазначити, що Б. Грегорі усвідомлює недоліки пізнього середньовіччя, указуючи на те, що в цей період християнство позначилося "прірвою між власними приписами віри та справжніми практиками багатьох християн, між своїми ідеалами та реаліями" [Gregory, 2012: 21]. Також автор стверджує, що його праця не $є$ ностальгією за "світом, який ми втратили". Однак, попри це, у книзі "Ненавмисна Реформація" все-таки $€$ помітною тенденція до ідеалізації католицької церкви середньовіччя, на чому наголошують дослідники у критичних оглядах цієї праці. Так, Д. Аерс та Р. Лео зауважують, що Б. Грегорі "ставить на ваги історичну модерність, ознаменовану Реформацією проти позачасової та ідеальної середньовічної церкви" [Aers, Leo, 2016: 466]. У результаті цієї ідеалізації Б. Грегорі у своєму дослідженні виділяє тільки негативні наслідки ідей Реформації, не помічаючи позитивних соціальних та світоглядних трансформацій, викликаних ідеями протестантизму.

Також зауважмо, що Ч. Тейлор займає більш помірковану позицію у своїх оцінках історичних явищ. Так, розглядаючи пізнє середньовіччя, він виділяє позитивні тенденції в межах латинського християнства, на основі яких постало наукове зацікавлення навколишнім світом. Разом із тим, канадський фрілософ констатує глибоку кризу середньовічної церкви, унаслідок якої виникає протестантизм. Так само, розглядаючи Реформацію, Ч. Тейлор виокремлює низку змін, що мали позитивний вплив на ранньомодерне європейське суспільство. Однак, попри це, він також зауважує, що, замість вирішення певних доктринальних питань середньовіччя, протестантизм загострив їх. Оскільки Реформація виникла на основі інтелектуального середовища като- 
лицької церкви, представники протестантизму перебрали судово-каральний стиль теології, який веде свій початок від Августина і знаходить теоретичне обґрунтування в Ансельма Кентерберійського. Як слушно зазначає Ч. Тейлор, юридичний характер теології, притаманний західному християнству, мав альтернативи, адже східні отці розглядали проблему людської гріховності, її наслідків та їі вирішення інакше. Однак проголошення "вчення про прокляття більшості людства чи вчення про подвійне наперед призначення" [Тейлор, 2013: 131] в теології Ж. Кальвіна призвело до несприйняття християнства гуманістами епохи Модерну. Це стало чинником ненавмисної дискредитації християнського вчення.

Нарешті, перейдімо до розгляду спільної для обох дослідників теми змін, спричинених Реформацією у сорері економіки. Ч. Тейлор зазначає, що в середньовічну епоху праця не цінувалась високо. Реформація, унаслідок перегляду низки доктрин, реабілітувала працю як вид соціальної діяльності. Разом із тим, поява протестантської етики праці надала поштовх до переосмислення жебрацтва. У середньовічній уяві бідняк $\epsilon$ необхідною складовою суспільства, зокрема приводом до освячення [Тейлор, 2013: 177]. У модерний час бідність переосмислюється як соціальна проблема, яка може загрожувати суспільному балансу, а отже, вона потребує вирішення.

Б. Грегорі розглядає вплив протестантизму на економіку по-іншому. Згідно з його поглядом, Реформація, ненавмисно спричинивши численні суперечки, призвела до того, що християни, будучи нездатними порозумітися в доктринальних питаннях, дійшли згоди в питанні влаштування власного комфортного життя [Gregory, 2012: 341]. Це стало передумовою того, що необмежене накопичення матеріальних благ перестало засуджуватися як жадібність та набуло рис соціальної чесноти. Згодом на цьому ґрунті відбудеться відокремлення економіки від етики, що призведе до появи споживацького характеру сучасного західного суспільства [Gregory, 2012: 233-234]

Як ми можемо бачити, обидва дослідники, розглядаючи спільні сфери впливу Реформації у процесі секуляризації, акцентують на різних її аспектах та в різний спосіб оцінюють ії наслідки. Ч. Тейлор у своєму наративі значною мірою слідує ідеям М. Вебера, виділяючи розчаклування навколишнього світу як один із найвизначніших результатів ідей протестантизму. Б. Грегорі не погоджується із твердженням про те, що ідеї Рефрормації призвели до розчаклування. На його думку, ототожнення середньовічного сакраментального світогляду з певного роду магією $€$ некоректним, оскільки воно базується на основі модерного натуралізму, який заперечує будь-який прояв трансцендентності в межах іманентного світу. Унаслідок цього зачаклованість світу як характерна риса середньовічного світогляду не постає як проблема в праці Б. Грегорі. Таким чином, ми можемо констатувати, що Ч. Тейлор та Б. Грегорі розходяться в поглядах щодо питання розчаклування світу як результату ідей Реформації.

Зазначимо, що твердження Б. Грегорі про формування доктрин протестантизму на основі метафрізичної однозначності буття не розглядається Ч. Тейлором. Також підкреслимо, що низка критичних зауважень ставить під сумнів тезу Б. Грегорі про вплив метафрізичної однозначності буття на ідеї реформаторів. Недостатня історична обґрунтованість цього зв'язку дає можливість стверджувати, що висновки Б. Грегорі, згідно з якими доктрини протестантизму створили передумови для наукового "спростування" існування Бога та сприяли появі "метафізичного натуралізму", $є$ непереконливими.

Водночас Ч. Тейлор та Б. Грегорі, прослідковуючи зміни, викликані Реформацією у сфері етики, розглядають різні рівні їх здійснення. Ч. Тейлор виділяє поширення моральних норм на широкі верстви населення як передумову до фрормування дисциплінарних суспільств. На думку канадського філософа, ці зміни постають фактором соціального поступу у формуванні модерних держав. Своєю чергою Б. Грегорі зосереджується на спричинених Реформацією етичних змінах, які відбулися через нездатність дійти згоди щодо цілої низки доктринальних питань. Зокрема, суб'єктивація моралі у світоглядній площині та заміна етики блага на етику прав на рівні держав постають ненавмисними негативними наслідками конфесійних поділень у межах протестантизму. Таким чином, відмінні аспекти досліджень Ч. Тейлора та Б. Грегорі щодо впливу Реформації у сфері етики не суперечать одні одним та можуть бути взаємодоповнюючими.

\section{Висновки}

Як ми можемо бачити, Ч. Тейлор у своїй концепції здебільшого зосереджує увагу на таких наслідках ідей протестантизму, що слугували розвитку тогочасних суспільств. Насамперед він виділяє розчаклування простору, поширення моральних стандартів та реабілітацію праці. Водночас, канадський філософ розглядає загострення доктринального питання про передвибрання в протестантизмі як одну з перешкод для сприйняття християнства інтелектуалами епохи Модерну. На противагу цьому, Б. Грегорі наголошує лише на тих наслідках Реформації, що мали негативний характер. Серед них він виділяє заперечення середньовічного сакраментального світогляду, суб'єктивацію моральних норм, а також необмежене накопичення матеріальних благ. Як зазначалося, попри недостатню обґрунтованість тверджень Б. Грегорі щодо передумов та наслідків заперечення в протестантизмі сакраментального світогляду, американський дослідник усе ж коректно демонструє такі спричинені Реформацією зміни, як суб'єктивація моралі та заміна етики блага на етику прав.

Проведений аналіз концепцій обох авторів дозволяє дійти висновку, що серед результатів Реформації були як такі, що сприяли соціальному поступу, так і ті, що призвели до появи нових етичних проблем. Це свідчить про те, що одностороння оцінка Реформації як винятково позитивного чи винятково негативного явища $€$ некоректною та не відповідає дійсності, оскільки не враховує множини ії прямих та опосередкованих, цілеспрямованих та ненавмисних наслідків. 3 огляду на це, можемо наголосити, що погляд Ч. Тейлора на Реформацію є більш поміркованим, оскільки дослідник намагається врахувати обидві сторони ії впливу, у той час як Б. Грегорі вбачає в ній лише деструктивний аспект.

\section{ЛІТЕРАТУРА}

Тейлор Ч. Секулярна доба / Пер. з англ. О. Панича. Київ: Дух і Літера, 2013. 661 с

Черенков М. Реформация и апокалипсис секулярности. Богословские размышления: Евро-Азиатский журнал богословия. 2017. № 19. С. 13-23.

Aers D., Leo R. Unintended Reformations? Journal of Medieval and Early Modern Studies. 2016. Vol. 46, No. 3. P. 455-483.

Gregory B. The Unintended Reformation: How a Religious Revolution Secularized Society. Cambridge; Massachusetts; London: The Belknap Press of Harvard University Press, 2012. $574 \mathrm{p}$.

\section{СХІД № 5 (157) вересень-жовтень 2018 р.}


Pennell J. Historical Supercessionism and the Challenge of the Unintended Reformation. URL: https://www.academia.edu/ 36961247/Historical Supercessionism and the Challenge_of_The_Unintended_Reformation (Дата звернення: 19.09.2018).

Peterson P. On Brad S. Gregory's The Unintended Reformation. Theologie. geschichte. 2014. Vol. 9. URL: http://universaar.uni-

Dziubak Roman,

Post-graduate student of the Department of Philosophy, Ivan Franko National University of Lviv

\section{THE INFLUENCE OF THE REFORMATIONAL FACTORS ON THE PROCESS OF SECULARIZATION}

This article explores the Reformation's influence on the secularization of Western society according to the conceptions of $\mathrm{Ch}$. Taylor and B. Gregory. Both authors point to the Reformation as a watershed moment in this process. However, they focus on different aspects of this historical phenomenon and assess its effects in contrasting ways.

In Ch. Taylor's book "A Secular Age" he reviews the Reformation in light of M. Webber's ideas and agrees that it has caused important reverberations, namely: disenchantment of time and space leading to the formation of instrumental reason, rehabilitation of work as a social activity and the spread of high moral standards to the masses, which then became a precondition for the formation of disciplinary societies. Hence, Ch. Taylor perceives the Reformation as a religious factor of predominant social progress. At the same time, he notices that the exacerbation of the doctrine of predestination in Protestantism became an obstacle for the intellectuals of the Modern Age to apprehend Christianity.

On the other hand, B. Gregory poses a more critical review of the Reformation in his book "The Unintended Reformation: How a Religious Revolution Secularized Society". He argues that doctrinal disagreements caused by Protestants' numerous convictions have consequently hindered contemporary Western society. Some of the unintended effects he identifies are the subjectivization of moral standards and the replacement of the substantial ethics of good by formal ethics of rights. Additionally, B. Gregory asserts that Protestant doctrines were influenced by the metaphysical univocity of being to a certain extent, which entailed the naturalistic character of modern science. However, several of his critics have questioned his research emphasizing the lack of evidence to support this last claim. Critics have also observed that his understanding of the Reformation as a destructive deviation from medieval Christianity is mainly based on an idealized view of the Middle Ages. Still, notwithstanding the one-sided character of B. Gregory's representation of the Reformation and the lack of reasonableness of some of his arguments, he correctly demonstrates its ethical consequences.

This allows the conclusion that among the Reformation's consequences were both, those that contributed to the social progress and those that led to the emergence of the new ethical problems. This mean that the one-sided assessment of the Reformation as an exclusively positive or entirely negative phenomenon is inaccurate since it does not take into account the plurality of its direct and indirect, intended and unintended consequences. In this respect, $\mathrm{Ch}$. Taylor is more moderate in his analysis of the Reformation, because he takes into consideration both aspects of its influence, in contrast to B. Gregory who notices only the destructive ones.

Key words: Reformation; secularization; Christianity; disenchantment; metaphysical univocity of being.

\section{REFERENCES}

Taylor, Ch., 2013. A Secular Age [translat.]. Kyiv: Dukh i Litera, 661 p.

Cherenkov, M., 2017. Reformation and the apocalypse of secularism. Theological Reflections: Euro-Asian Journal of Theology, Vol. 19, pp.13-23.

Aers, D. and Leo, R., 2016. Unintended Reformations? Journal of Medieval and Early Modern Studies, Vol. 46, Issue 3, pp. 455-483.

Gregory, B., 2012. The Unintended Reformation: How a Religious Revolution Secularized Society. Cambridge; Massachusetts; London: The Belknap Press of Harvard University Press, $574 \mathrm{p}$.

Pennell, J., 2018. Historical Supercessionism and the Challenge of The Unintended Reformation. [online] Available at: https:// www.academia.edu/36961247/Historical_Supercessionism_and the Challenge of The_Unintended Reformation [Accessed 19 September 2018].

Peterson, P., 2014. On Brad S. Gregory's The Unintended Reformation. Theologie. geschichte, [online] 9. Available at: http:// universaar.uni-saarland.de/journals/index.php/tg/article/view/656/701 [Accessed 19 September 2018].

Reeves, J., 2017. How Not to Link the Reformation and Science: Reflections on Brad Gregory's The Unintended Reformation. Religions, pp. 113-118.

Smith, J., 2014. How (Not) to Be Secular. Reading Charles Taylor. Grand Rapids: William B. Eerdmans Publishing Company, 148 p.

(C) Дзюбак Роман

Надійшла до редакції 05.10.2018 